\title{
NTRK/ROS1 Inhibitor DS-6051b
}

National Cancer Institute

\section{Source}

National Cancer Institute. NTRK/ROS1 Inhibitor DS-6051b. NCI Thesaurus. Code C118948.

An orally available inhibitor of the receptor tyrosine kinases C-ros oncogene 1 (ROS1) and the neurotrophic tyrosine receptor kinase (NTRK) types 1, 2 and 3, with potential antineoplastic activity. Upon oral administration, DS-6051b binds to and inhibits ROS1 and the NTRK family members. This inhibition leads to a disruption of ROS1- and NTRKmediated signaling and eventually inhibits the growth of tumor cells that are overexpressing ROS1 and/or NTRKs. ROS1, overexpressed in certain cancer cells, plays a key role in cell growth and survival of cancer cells. NT RK mutations or rearrangements play a key role in cancer progression. 